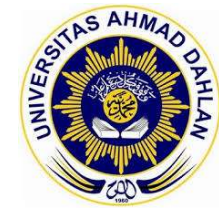

BERKALA FISIKA INDONESIA

Jurnal IImiah Fisika, Pembelajaran dan Aplikasinya

http://journal.uad.ac.id/index.php/BFl/index

2085-0409 (Print) |2550-0465 (online)

\title{
Peningkatan keaktifan belajar fisika rangkaian listrik tertutup sederhana berbantuan powerpoint pada siswa SMA
}

\author{
Agustinus Suwondo ${ }^{1 *}$, Moh. Irma Sukarelawan ${ }^{2}$, Sriyanto ${ }^{3}$ \\ ${ }^{1}$ SMAN 1 Bambanglipuro, Indonesia \\ ${ }^{2}$ Magister Pendidikan Fisika, Fakultas Keguruan dan Ilmu Pendidikan, Universitas Ahmad Dahlan, Indonesia \\ ${ }^{3}$ SMAN 2 Bantul, Indonesia \\ Email: suwondoag66@gmail.com* \\ * Penulis korespondensi
}

\begin{tabular}{ll}
\hline \multicolumn{2}{l}{ Informasi artikel } \\
\hline Sejarah artikel: & \\
Dikirim & $16 / 03 / 21$ \\
Revisi & $07 / 04 / 21$ \\
Diterima & $09 / 04 / 21$ \\
\hline
\end{tabular}

\section{Kata kunci:}

Keaktifan belajar

Media powerpoint

Penelitian tindakan kelas

Rangkaian listrik tertutup

\section{Keywords:}

Learning activeness

Powerpoint media

Classroom action research

Closed electrical circuit

\begin{abstract}
ABSTRAK
Tujuan penelitian ini adalah untuk meningkatkan keaktifan belajar fisika siswa pada materi rangkaian listrik tertutup sederhana menggunakan media powerpoint. Penelitian ini menggunakan model Penelitian tindakan kelas (PTK) sebanyak dua siklus. Kegiatan penelitian dilaksanakan pada kelas X.2 di SMAN 1 Srandakan Bantul. Pengumpulan data menggunakan angket keaktifan yang terdiri atas 9 aspek. Siklus penelitian dianggap cukup jika persentase keaktifan siswa tiap aspek dan keaktifan rata-rata kelas lebih dari $77 \%$. Hasil penelitian menunjukkan rata-rata keaktifan siswa meningkat sebesar $30,69 \%$. Persentase keaktifan pada siklus 1 sebesar $66,14 \%$ dan pada siklus 2 sebesar $96,83 \%$. Jadi dapat disimpulkan bahwa penggunaan media powerpoint dapat meningkatkan keaktifan belajar siswa pada materi rangkaian listrik tertutup sederhana.
\end{abstract}

This is an open access article under the CC-BY-SA license

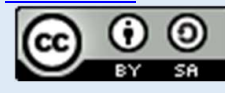

\section{ABSTRACT}

Increasing the activeness of learning physics with a simple closed circuit with powerpoint assistance to high school students. The purpose of this study was to increase students' learning activity of physics in simple closed circuit material using powerpoint media. This study used a classroom action research (CAR) model with two cycles. The research activity was carried out in class X.2 at SMAN 1 Srandakan, Bantul. Collecting data using an activeness questionnaire which consists of 9 aspects. The research cycle is considered sufficient if the percentage of student activity in each aspect and the average activity of the class is more than $77 \%$. The results showed that the average activity of the students increased by $30.69 \%$. The percentage of activeness in cycle 1 was $66.14 \%$ and cycle 2 was $96.83 \%$. So it can be concluded that the use of powerpoint media can increase student learning activeness in simple closed circuit material.

\section{How to Cite:}

Suwondo, A., Sukarelawan, M. I., \& Sriyanto. (2021). Peningkatan keaktifan belajar fisika rangkaian listrik tertutup sederhana berbantuan powerpoint pada siswa SMA. Berkala Fisika Indonesia: Jurnal Ilmiah Fisika, Pembelajaran dan Aplikasinya, 12(2), 54-59. 


\section{Pendahuluan}

Ilmu yang sangat berkaitan erat dengan kehidupan manusia salah satunya adalah ilmu fisika. Wujud dari ilmu fisika dapat berbentuk teknologi yang bermanfaat bagi manusia. Teknologi canggih yang merupakan salah satu wujud dari keberadaan ilmu fisika dapat meringankan pekerjaan. Teknologi merupakan hasil dari gabungan beberapa konsep fisika. Perkembangan teknologi atau peralatan yang digunakan oleh manusia salah satunya didasari oleh adanya ilmu fisika. Teknologi yang telah diciptakan dapat diperbarui dengan adanya penemuan-penemuan baru dalam bidang fisika (Harefa, 2019).

Setiap proses pembelajaran fisika kelas X SMA Negeri 1 Srandakan, beberapa siswa masih sangat pasif dan kurang semangat dalam mengerjakan tugas seperti soal-soal yang ada pada buku LKS. Faktor tempat belajar, kondisi fisik siswa, intelektualitas siswa, fasilitas, durasi belajar, pola belajar siswa, guru, orang tua, kondisi mental siswa, dan faktor kesehatan siswa merupakan faktor-faktor yang dapat mempengaruhi motivasi belajar siswa (Muthmainnah \& Rokhmat, 2017; Rohman \& Karimah, 2018; Putri et al., 2017).

Pengetahuan tentang rangkaian listrik pembelajaran fisika di kelas $X$ masih sangat abstrak untuk para siswa kelas $X$ di SMA N 1 Srandakan. Data prestasi siswa kelas $X$, masih belum memenuhi rata-rata Kriteria Ketuntasan Minimal (KKM) yaitu 75. Hal ini terbukti dari 22 siswa yang memperoleh nilai sesuai KKM sekolah belum mencapai $100 \%$. Terciptanya alat komunikasi baik secara lisan maupun tertulis merupakan bentuk tercapainya kompetensi dasar fisika. Proses pembelajaran fisika di SMA Negeri 1 Srandakan selama ini hanya menekankan pada pencapaian kurikulum dan pencapaian nilai semata, kurang dalam hal pengembangan kemampuan belajar. Kecenderungan siswa yang kurang terlibat dan semangat belajar berkontribusi pada buruknya hasil belajar. Ini mendorong mereka untuk menunggu presentasi guru daripada mencari dan memperoleh keahlian dan keterampilan yang mereka butuhkan.

Kegiatan belajar mengajar dengan menggunakan berbagai pendekatan dan menggunakan metode yang sesuai dengan perkembangan siswa perlu dilakukan. Penggunaan metode belajar yang tepat akan berpengaruh terhadap hasil belajar siswa (Syafruddin, 2017). Hal tersebut juga memberikan peluang bagi para guru agar selalu kreatif, inovatif serta berekspresi dalam mengembangkan kemampuan diri secara optimal. Menurut penelitian Khayati dan Sarjana (2015), guru yang memiliki efikasi diri yang tinggi akan dapat meningkatkan kreativitas dan inovasi. Oleh karena itu, peneliti bermaksud ingin mengadakan pengubahan pola belajar anak dengan harapan siswa menjadi lebih bersemangat, kreatif, dan senang dalam mengikuti pembelajaran di kelas. Melihat masalah di atas, peneliti berinisiatif untuk menerapkan metode pembelajaran yang tepat sehingga dalam proses pembelajaran siswa tidak hanya berstatus sebagai pendengar melainkan juga ikut aktif dalam pembelajaran. Keaktifan siswa selama pembelajaran di kelas berpengaruh terhadap prestasi siswa belajar baik secara simultan maupun secara parsial (Chozaipah, 2018). 
Adapun inovasi yang dicoba dalam upaya meningkatkan prestasi belajar fisika di SMA Negeri 1 Srandakan adalah penggunaan variasi media belajar yang tidak membosankan serta menarik bagi siswa. Media yang digunakan peneliti dalam pembelajaran rangkaian arus listrik adalah media powerpoint. Belajar dengan media powerpoint diharapkan dapat memacu semangat belajar anak sehingga dapat mendongkrak perolehan hasil yang lebih baik dan nilai siswa diharapkan akan sesuai dengan KKM sekolah. Oleh karena itu, penelitian ini bertujuan untuk meningkatkan keaktifan belajar fisika siswa pada materi rangkaian listrik tertutup sederhana berbantuan Powerpoint.

\section{Metode}

Penelitian Tindakan Kelas (PTK) ini mengadopsi model yang diusulkan oleh Kemmis dan Taggart. PTK dilakukan di kelas X.2 SMA 1 Srandakan Kabupaten Bantul. PTK dilakukan dalam 2 siklus. Tiap siklus melewati tahap perencanaan, tindakan, pengamatan, dan refleksi. Jumlah siswa yang terlibat sebanyak 22 orang (10 laki-laki dan 12 perempuan). Instrumen yang telah digunakan dalam PTK terdiri atas lembar observasi/monitoring kelas, lembar wawancara, angket keaktifan belajar, dan dokumentasi. Keaktifan siswa ditinjau dari 9 aspek dan ditunjukkan dalam Tabel 1.

Tingkat keaktifan siswa dianalisis secara deskriptif, yaitu menggunakan teknik persentase. Kriteria tingkat keaktifan siswa dibagi ke dalam 5 kelompok dan mengacu pada Tabel 2. Siklus pembelajaran akan dianggap mencukupi jika persentase keaktifan tiap aspek dan keaktifan siswa secara keseluruhan mencapai $77 \%$ atau masuk kategori tinggi.

\begin{tabular}{cl}
\multicolumn{2}{c}{ Tabel 1. Aspek keaktifan siswa } \\
\hline Aspek & \multicolumn{1}{c}{ Jenis keaktifan } \\
\hline 1 & Memperhatikan \\
2 & Mencatat \\
3 & Mengajukan pendapat \\
4 & Merespon pertanyaan \\
5 & Mengerjakan soal \\
6 & Mengerjakan LKS \\
7 & Mempresentasikan hasil \\
8 & Memanfaatkan sumber belajar \\
9 & \\
& \\
Tabel 2. Kriteria tingkat keaktifan siswa \\
\hline Persentase & Tingkat keaktifan \\
\hline $\mathrm{p} \geq 80 \%$ & Sangat tinggi \\
$77 \% \leq p<80 \%$ & Sedang \\
$55 \% \leq p<77 \%$ & Rendah \\
$40 \% \leq p<55 \%$ & Sangat rendah \\
$p<40 \%$ & $p=$ persentase keaktifan siswa
\end{tabular}

\section{Hasil dan Pembahasan}

Penelitian ini bertujuan untuk meningkatkan keaktifan siswa melalui penggunaan media pembelajaran fisika powerpoint pada materi rangkaian listrik tertutup. Keaktifan siswa pada siklus 1 dan 2 dijelaskan berikut. 
Siklus 1

Tingkat keaktifan siswa pada pembelajaran siklus 1 ditampilkan dalam Gambar 1. Berdasarkan Gambar 1, keaktifan siswa masih belum memenuhi kriteria yang ditentukan karena persentase keaktifan rata-rata kelas sebesar $66,14 \%$. Nilai ini masih di bawah nilai standar. Persentase terrendah berada pada aspek "mempresentasikan hasil" yaitu sebesar 29,29\%. Sedangkan persentase tertinggi berada pada aspek "memperhatikan" yaitu sebesar $86,43 \%$.

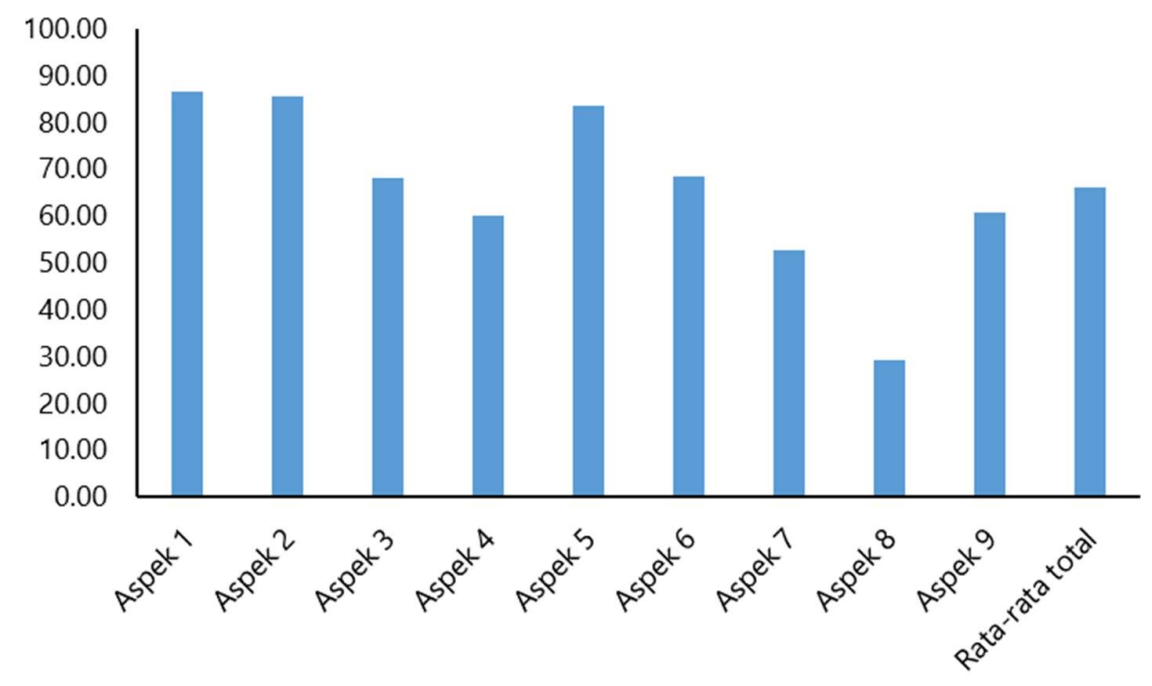

Gambar 1. Tingkat keaktifan siswa pada pembelajaran siklus 1

Mempresentasikan hasil memiliki persentase keaktifan terendah; Peneliti telah menunjukkan bahwa siswa juga kurang berminat mempresentasikan hasil, dan siswa masih malu saat mengajukan pertanyaan kepada guru. Ini mungkin dianggap sebagai kurangnya kepercayaan diri pada keterampilan siswa. Modal fundamental paling kritis dalam kemampuan seseorang untuk mengaktualisasikan dirinya adalah kepercayaan diri. Percaya diri adalah salah satu hasil aktualisasi diri yang optimis; Memiliki rasa percaya diri membantu siswa untuk menumbuhkan kekuatan, keinginan, dan potensinya untuk menjadi baik atau mencapai kesuksesan (Komara, 2016). Kepercayaan diri remaja dapat tercermin dari penghargaan terhadap diri sendiri apa adanya (Fitri et al., 2018). Kepercayaan pada keterampilan, motivasi, objektivitas, komitmen, logika, dan realisme seseorang adalah faktor yang memengaruhi kepercayaan diri (Fitri et al., 2018).

Siklus 2

Tingkat keaktifan siswa pada pembelajaran siklus 2 ditampilkan dalam Gambar 2. Berdasarkan tindakan kelas pada siklus II, terjadi peningkatan keaktifan siswa dalam mengikuti proses pembelajaran. Pada siklus I rata-rata kelas $66,14 \%$ sedangkan pada siklus II rata-rata kelas $96,83 \%$ sehingga dalam siklus II terjadi kenaikan rata-rata kelas sebesar 30,69\%. Rata-rata persentase keaktifan siswa pada setiap aspek mengalami peningkatan, peningkatan tertinggi terjadi pada aspek "mempresentasikan hasil" 
yaitu sebesar 65,95\%. Sedangkan peningkatan terrendah pada aspek "Memperhatikan" yaitu sebesar 13,57\%. Sedangkan aspek Mencatat, Mengajukan pendapat, Merespon pertanyaan, Berdiskusi, Mengerjakan soal, Mengerjakan LKS, dan Memanfaatkan sumber belajar mengalami peningkatan masing-masing sebesar $14.29 \%, 27.12 \%, 35.24 \%, 16.43 \%$, 26.67\%, 42.38\%, dan 34.53\%.

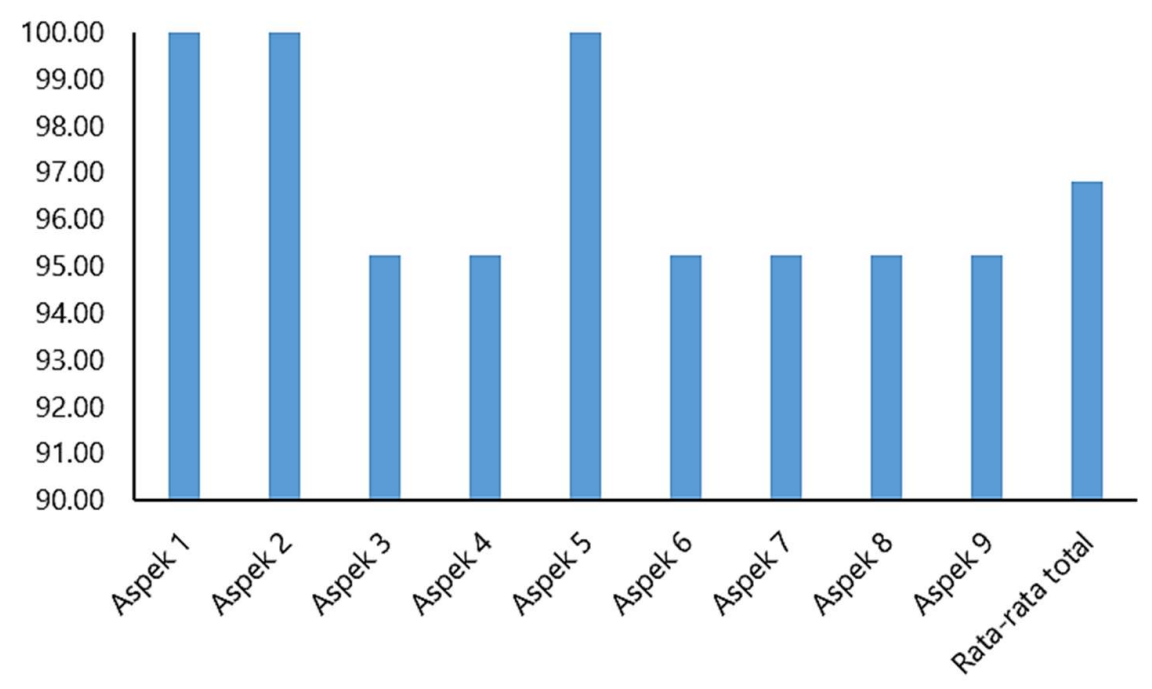

Gambar 2. Tingkat keaktifan siswa pada pembelajaran siklus 2

Persentase keaktifan siswa pada Siklus II pada setiap aspek sangat tinggi, sehingga rata-ratanya di atas nilai standar yang ditentukan sekolah. Seluruh aspek yang dinilai memiliki pengaruh terhadap prestasi belajar siswa. Berbagi hasil kelompok, meminta umpan balik, dan menanggapi pertanyaan guru, menanamkan keberanian dan kepercayaan diri pada siswa. Salah satu karya aktualisasi diri produktif adalah rasa percaya diri. Siswa dapat mengembangkan keterampilan, keinginan, dan potensi mereka untuk sukses atau mencapai kesuksesan dengan memiliki kepercayaan diri (Komara, 2016). Bagian dari mencatat yang melibatkan perilaku dapat digunakan untuk memprediksi keterampilan memori sikap. Ketika orang memiliki pola pikir mencatat, mereka dapat melihat bagaimana kemampuan ingatan setiap orang (Dewi \& Indrawati, 2014). Salah satu ciri siswa dengan gaya belajar visual adalah tidak dapat mengikuti pelajaran secara lisan. Mereka sering salah memahami frasa atau ucapan. Namun, menulis catatan memungkinkan mereka mengingat apa yang telah mereka pelajari (Uno, 2010).

Berdiskusi atau berpartisipasi dalam kelompok berkontribusi dalam peningkatan prestasi belajar siswa (Pono \& Lutfi, 2012). Kerjasama dan hubungan sosial, mengemukakan pendapat atau ide, dan pemecahan masalah merupakan indikator keaktifan siswa (Wibowo, 2016). Aspek mengerjakan soal oleh siswa juga dapat meningkatkan prestasi belajar pada siswa (Yusmalia, Sumaidi, \& Yarmaidi, 2011), mengerjakan tugas merupakan komponen dengan sumbangan terbesar terhadap prestasi belajar (Sausan \& Mulyani, 2016).

Sarana dan prasarana juga mempunyai pengaruh yang signifikan terhadap motivasi intrinsik dan ekstrinsik belajar siswa. Penggunaan sarana prasarana belajar dapat meningkatkan prestasi belajar pada 
siswa. Sumber belajar juga berpengaruh terhadap peningkatan prestasi belajar siswa (Djelesia, Ahmad, \& Djirimu, 2010).

\section{Simpulan}

Berdasarkan hasil penelitian dan pembahasan dapat diambil kesimpulan, bahwa penerapan model pembelajaran fisika menggunakan media powerpoint dapat meningkatkan keaktifan belajar siswa kelas X.2 SMA Negeri 1 Srandakan. Pada Siklus I, keaktifan siswa masih tergolong rendah, yaitu sebesar 69,57\%. Namun, pada Siklus II ada peningkatan keaktifan siswa dalam mengikuti proses pembelajaran dengan rata-rata kelas sebesar 96,83\%. Ada kenaikan rata-rata kelas dari Siklus I dan Siklus II sebesar 19,32\%. Peningkatan keaktifan tertinggi pada aspek "Mempresentasikan hasil" dan peningkatan terendah terjadi pada aspek "Memperhatikan".

\section{Referensi}

Chozaipah. (2018). Peran dan partisipasi siswa dalam pembelajaran terhadap prestasi belajar akuntansi di SMKN 1 Dumai provinsi Riau. Jurnal Serambi PTK, 5(1), 60-65.

Dewi, I. A. G. B. P., \& Indrawati, K. R. (2014). Perilaku mencatat dan kemampuan memori pada proses belajar. Jurnal Psikologi Udayana, 1(2), 241-250.

Djelesia, Ahmad, M., \& Djirimu, M. (2010). Meningkatkan hasil belajar siswa kelas IV MIS Tompo melalui pemanfaatan lingkungan sekolah sebagai sumber belajar IPA. Jurnal Kreatif Tadulako, 4(5), 194-208.

Fitri, E., Zola, N., \& Ifdil, I. (2018). Profil kepercayaan diri remaja serta faktor-faktor yang mempengaruhi. JPPI (Jurnal Penelitian Pendidikan Indonesia), 4(1), 1-5.

Harefa, A. R. (2019). Peran ilmu fisika dalam kehidupan sehari-hari. Warta Dharmawangsa, 13(2), 1-10.

Khayati, N., \& Sarjana, S. (2015). Efikasi diri dan kreativitas menciptakan inovasi guru. Jurnal Pendidikan dan Kebudayaan, 21(3), 243-262.

Komara, I. B. (2016). Hubungan antara kepercayaan diri dengan prestasi belajar dan perencanaan karir siswa SMP. Psikopedagogia: Jurnal Bimbingan dan Konseling, 5(1), 33-42.

Muthmainnah, M., \& Rokhmat, J. (2017). Pengaruh penerapan metode pembelajaran fisika berbasis eksperimen virtual terhadap motivasi dan hasil belajar fisika siswa kelas X MAN 2 Mataram tahun ajaran 2014/2015. Jurnal Pendidikan Fisika Dan Teknologi, 3(1), 40-47.

Pono, N., \& Lutfi, M. (2012). Pengaruh pembelajaran menggunakan metode diskusi kelompok terhadap prestasi belajar siswa pada pokok bahasan geometri dimensi tiga di MAN Kalimukti Kec. Pabedilan Kab. Cirebon. EduMa, 1(2), 63-72.

Putri, R. H., Lesmono, A. D., \& Aristya, P. D. (2017). Pengaruh model discovery learning terhadap motivasi belajar dan hasil belajar fisika siswa MAN Bondowoso. Jurnal Pembelajaran Fisika, 6(2), 168-174.

Rohman, A. A., \& Karimah, S. (2018). Faktor-Faktor yang Mempengaruhi Rendahnya Motivasi Belajar Siswa Kelas XI. At-Taqaddum, 10(1), 95-108.

Sausan, I., \& Mulyani, S. (2016). Faktor-faktor internal yang berpengaruh terhadap prestasi belajar siswa pada pokok bahasan konsep mol. PAEDAGOGIA Jurnal Penelitian Pendidikan, 19(1), 79-89.

Syafruddin, S. (2017). Implementasi metode diskusi terhadap peningkatan hasil belajar siswa. CIRCUIT: Jurnal Ilmiah Pendidikan Teknik Elektro, 11(1), 9-16.

Uno, H. B. (2010). Orientasi baru dalam psikologi pembelajaran. Jakarta: PT. Bumi Aksara.

Wibowo, N. (2016). Pembelajaran berdasarkan gaya belajar di SMK negeri 1 Saptosari. Elinvo (Electronics, Informatics, and Vocational Education), 1(2), 128-139.

Yusmalia, Y., Sumaidi, \& Yarmaidi. (2011). Hubungan cara belajar dengan prestasi belajar mata pelajaran geografi siswa kelas XI IPS SMA perintis I Bandar Lampung tahun pelajaran 2010/2011. Jurnal Penelitian Geografi, 22(3), 256-278.

p-ISSN 2085-0409

e-ISSN 2550-0465
Berkala Fisika Indonesia : Jurnal Ilmiah Fisika, Pembelajaran dan Aplikasinya Vol. 12 No. 2, Juli 2021 | $54-59$ 